\title{
KAJIAN TAFSIR MUNIR KARYA WAHBAH AZ-ZUHAYLI
}

\author{
Moch. Yunus*
}

Abstract: This paper examines the exegesis of al-Munir by Wabbah az-Zubayli, Tafsir al-Munir is a classical commentary packed with contemporary language and combines the classical interpretive orientalist and the beauty of his interpretation so easily understood. This commentary is written because the Wabbah is concerned over the view of the classical commentary that offers no solution to contemporary problems. The method used is the tablili method whose interpretation at the beginning of each letter takes precedence over the virtue and the contents of the letter. And his tafsir style combines the interpretation of bi al-Ra'yi and the interpretation bi al-Riwayah. In tafsirnya there are two aspects of aspects of worship and the second aspect of muamalat.

Keywords: Wabbah az-Zuhayli, Tafsir al-Munir,

\section{A. Pendahuluan}

Al-Qur'an dengan isinya yang mudah dan kandungan makna yang sangat luas memerlukan penafsiran untuk memahami kandungannya, oleh karenanya pasca Rasul wafat muncul beberapa penafsiran dari para sahabat dan generasi sesudahnya.

Suatu hal yang dapat membantu memahami apa yang terkandung di dalam al-Qur'an adalah turunnya al-Qur'an secara berangsur-angsur sesuai dengan peristiwa-peristiwa atau kejadian yang menimpa umat Islam,

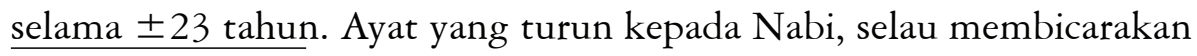

* Dosen tetap Institut ilmu keislaman Zainul Hasan Genggong Kraksaan Probolinggo 
permasalahan yang ketika itu sedang dialami oleh umat Islam. Oleh karena itu, secara langsung Rasulullah dan para sahabatnya mempelajari makna yang dikandung al-Qur'an. Rasulullah berupaya menjelaskan makna ayat yang global, menjelaskan pengertian yang masih samara, dan memecahkan berbagai problema yang mereka hadapi sehingga mereka tidak merasa ragu lagi terhadap kandungan al-Qur'an. Ketika itu Rasulullah benar-benar berfungsi sebagai penyuluh yang mampu menunjukkan jalan yang lurus, sekaligus menjelaskan pengertianpengertian agama yang sulit dicerna oleh para sahabat. Rasulullah juga sebagai penafsir al-Qur-an dengan sunnah-sunnah beliau baik Qauli maupun Fi'li.

Banyak para Mufassir yang menafsirkan ayat-ayat al-Qur'an dengan metode dan corak yang berbeda-beda, akant teatapi beda dengan Wahbah az-Zuhayli seorang ahli Fiqh yang berusaha menguraikan ayat-ayat alQur'an, dengan sumber, metode, corak, dan karakteristik yang khas.

Disini penulis akan menguraikan tentang biografi Wahbah azZuhayli, karya-karya, aliran, metode serta keistimewaan dan kelebihan dalam tafsirnya.

\section{B. Pembahasan}

\section{Riwayat hidup Wahbah az-Zuhayli}

Wahbah az-Zuhayli lahir di Dair 'Atiyah yang terletak dipelosok kota Damaskus, Suriah, pada tahun 1351 H/1932 M. Nama Lengkapnya Wahbah bin Must $\}$ afa az-Zuhayli. Ia putera syaikh Musthafa az-Zuhayli, seorang petani sederhana nan alim, hafal al-Qur'an, rajin beribadah, dan gemar berpuasa. Dibawah bimbingan ayahnya, Wahbah mengenyam dasar-dasar agama Islam . Setelah itu, ia bersekolah di Madrasah Ibtidaiyah di kampungnya, hingga jenjang pendidikan formal berikutnya. Gelar sarjana diraihnya pada tahun 1953 M di Fakultas Shari'ah Universitas Damaskus. Tahun 1956 M. ia meraih gelar doktor dalam bidang Shari'ah dari Universitas al-Azhar, Kairo ${ }^{1}$

Pada tahun 1963 M, ia diangkat sebagai dosen di Fakultas Shari'ah Universitas Damaskus dan secara berturut-turut menjadi Wakil Dekan,

1 Saiful Amin Ghofur, Profil Para Mufasir Al-Qur'an, 2008, (Yogyakarta: Pustaka Insan Madani), 174 
kemudian Dekan dan Ketua Jurusan Fiqh Islami wa Madhahabih di Fakultas yang sama. Ia mengabdi selama lebih dari tujuh tahun dan dikenal alim dalam bidang Fiqh, Tafsir dan Dirasab Islamiyyah. ${ }^{2}$

\section{Karya-karyanya}

Wahbah al-Zuhayli menulis buku, kertas kerja dan artikel dalam berbagai ilmu Islam. Buku-bukunya melebihi 133 buah buku dan jika dicampur dengan risalah-risalah kecil melebihi lebih 500 makalah. Satu usaha yang jarang dapat dilakukan oleh ulama kini seolah-olah ia merupakan as-Suyuti kedua (as-Sayuti al-Thani) pada zaman ini, mengambil sampel seorang Imam Shafi'iyyah yaitu Imam al-Sayuti. diantara buku-bukunya adalah sebagai berikut :

a. Athar al-Harb fi al-Fiqh al-Islami - Dirasat Muqaranah, Dar al-Fikr, Damsyiq, 1963.

b. Al-Wasit fi Usul al-Fiqh, Universiti Damsyiq, 1966.

c. Al-Fiqh al-Islami fi Uslub al-Jadid, Maktabah al-Hadithah, Damsyiq, 1967.

d. Nazariat al-Darurat al-Syar'iyyah, Maktabah al-Farabi, Damsiq, 1969.

e. Nazariat al-Daman, Dar al-Fikr, Damsyiq, 1970.

f. Al-Ushul al-Ammah li Wahdah al-Din al-Haq, Maktabah alAbassiyah, Damsyiq, 1972.

g. Al-Alaqat al-Dawliah fi al-Islam, Muassasah al-Risalah, Beirut, 1981.

h. Al-Fiqh al-Islami wa Adilatuh, (8 jilid), Dar al-Fikr, Damsyiq, 1984. (Ini dia Kitab rujukan utama utk beberapa mata kuliahku dulu, sipp bngt )

i. Usul al-Fiqh al-Islami (dua Jilid), Dar al-Fikr al-Fikr, Damsyiq, 1986.

j. Juhud Taqnin al-Fiqh al-Islami, (Muassasah al-Risalah, Beirut, 1987.

k. Fiqh al-Mawarith fi al-Shari'at al-Islamiyah, Dar al-Fikr, Damsyiq, 1987.

1. Al-Wasaya wa al-Waqf fi al-Fiqh al-Islami, Dar al-Fikr, Damsyiq, 1987.

m. Al-Islam Din al-Jihad La al-Udwan, Persatuan Dakwah Islam Antarabangsa, Tripoli, Libya, 1990.

${ }^{2}$ http://referensiagama.blogspot.com/2011/01/sekilas-tentang-tafsir-munir. html 
n. al-Tafsir al-Munir fi al-Aqidah wa al-Shari'at wa al-Manhaj, (16 jilid), Dar al-Fikr, Damsyiq, 1991.

o. al-Qisah al-Qur'aniyyah Hidayah wa Bayan,Dar Khair, Damsyiq, 1992.

p. Al-Qur'an al-Karim al-Bunyatuh al-Tasyri'iyyah aw Khasa'isuh alHadariah, Dar al-Fikr, Damsyiq, 1993.

q. al-Rukhsah al-Syari'at - Ahkamuha wa Dawabituha, Dar al-Khair, Damsyiq, 1994.

r. Khasa'is al-Kubra li Huquq al-Insan fi al-Islam, Dar al-Maktabi, Damsyiq, 1995.

s. Al-Ulum al-Shari'at Bayn al-Wahdah wa al-Istiqlal, Dar al-Maktab, Damsyiq, 1996.

t. Al-Asas wa al-Masadir al-Ijtihad al-Mushtarikat bayn al-Sunnah wa al-Shiah, Dar al-Maktabi, Damsyiq, 1996.

u. Al-Islam wa Tahadiyyat al-'Asr, Dar al-Maktabi, Damsyiq, 1996.

v. Muwajahat al-Ghazu al-Thaqafi al-Sahyuni wa al-Ajnabi, Dar alMaktabi, Damsyiq, 1996.

w. al-Taqlid fi al-Madhahib al-Islamiah 'inda al-Sunnah wa al-Shiah, Dar al-Maktabi, Damsyiq, 1996

x. Al-Ijtihad al-Fiqhi al-Hadith, Dar al-Maktabi, Damsyiq, 1997.

y. Al-Uruf wa al-Adat, Dar al-Maktabi, Damsyiq, 1997.

z. Bay al-Asham, Dar al-Maktabi, Damsyiq, 1997.

aa. Al-Sunnah al-Nabawiyyah, Dar al-Maktabi Damsyiq, 1997.

ab. Idarat al-Waqaf al-Khairi, Dar al-Maktabi, Damsyiq, 1998.

ac. al-Mujadid Jamaluddin al-Afghani, Dar al-Maktabi, Damsyiq, 1998.

ad. Taghyir al-Ijtihad, Dar al-Maktabi, Damsyiq, 2000.

ae. Tat \}biq al-Shari'at al-Islamiah, Dar al-Maktabi, Damsyiq, 2000.

af. Al-Zira'i fi al-Siyasah al-Shar'iyyah wa al-Fiqh al-Islami, Dar alMaktabi, Damsyiq, 1999.

ag. Tajdid al-Fiqh al-Islami, Dar al-Fikr, Damsyiq, 2000.

ah. Al-Thaqafah wa al-Fikr, Dar al-Maktabi, Damsyiq, 2000.

ai. Manhaj al-Da'wah fi al-Sirah al-Nabawiyah, Dar al-Maktabi, Damsyiq, 2000.

aj. Al-Qayyim al-Insaniah fi al-Qur'an al-Karim, Dar al-Maktabi, Damsyiq, 2000.

ak. Haq al-Hurriah fi al-'Alam, Dar al-Fikr, Damsyiq, 2000. 
al. Al-Insan fi al-Qur'an, Dar al-Maktabi, Damsyiq, 2001.

am. Al-Islam wa Usul al-Hadarah al-Insaniah, Dar al-Maktabi, Damsyiq, 2001.

an. Usul al-Fiqh al-Hanafi, Dar al-Maktabi, Damsyiq, 2001. ${ }^{3}$

\section{Metode kitab tafsir al-Munir}

Metode yang berkembang dalam penafsiran al-Qur'an terdapat empat macam,yakni:

a. Tablili, yaitu metode penafsiran al-Qur'an yang dilakukan dengan cara menjelaskan ayat al-Qur'an dalam berbagai aspek, serta menjelaskan maksud yang terkandung didalamnya sehingga kegiatan mufasir hanya menjelaskan per ayat, per surat, makna lafal tertentu, susunan kalimat, persesuaian kalimat lain, asbab an-Nuzul yang berkenaan dengan ayat yang ditafsirkan.

b. Ijmali, yaitu metode penafsiran al-Qur'an yang dilakukan dengan car menjelaskan maksud al-Qur'an secara global tidak terperinci seperti tafsir tahlili, hanya saja penjelasannya disebutkan secara global (ijmal).

c. Muqarin, yaitu metode penafsiran al-Qur'an yang dilakukan dengan cara perbandingan (komparatif), dengan menemukan dan mengkaji perbedaan-perbedaan antara unsur-unsur yang diperbandingkan, baik dengan menemukan unsur yang benar diantara yang kurang benar.

d. Maudhu'i, metode penafsiran al-Qur'an yang dilakukan dengan cara memilih topik tertentu yang hendak dicarikan penjelasannya dalam al-Qur'an yang berhubungan dengan topik ini, lalu dicarilah kaitan antara berbagai ayat ini agar satu sama lain bersifat menjelaskan. ${ }^{4}$

Dengan mengamati beberapa metode yang terdapat dalam beberapa kitab 'Ulum al-Qur'an. Secara metodis sebelum memasuki bahasan ayat, Wahbah az-Zuhayli pada setiap awal surat selalu mendahulukan penjelasan tentang keutamaan dan kandungan surat tersebut, dan sejumlah tema yang terkait dengannya secara garis besar. Setiap tema yang diangkat dan dibahas mencakup aspek bahasa, dengan menjelaskan beberapa istilah yang termaktub dalam sebuah ayat, dengan menerangkan

${ }^{3}$ http://denchiel78.blogspot.com//2010/05/bioigrafi-singkat -wahbah-zuhaili. html

${ }^{4}$ Muhaimin, Kawasan dan Wawasan Studi Islam, (Jakarta: Prenada Media, 2005), 113-116 
segi-segi balaghah dan gramatika bahasanya. ${ }^{5}$

Dengan demikian metode penafsiran yang dipakai adalah metode tahlili ${ }^{6}$ dan semi tematik, karena beliau menafsirkan al-Qur'an dari surat al-Fatihah sampai dengan surat an-Nas dan memberi tema pada setiap kajian ayat yang sesuai dengan kandungannya, seperti dalam menafsirkan surat al-Baqarah ayat satu sampai lima, beliau memberi tema sifat-sifat orang mukmin dan balasan bagi orang-orang yang bertaqwa. ${ }^{7}$ Dan seterusnya sampai surat an-Nas selalu memberi tema bahasan di setiap kelompok ayat yang saling berhubungan. Menguraikan makna yang dikandung oleh al-Qur'an, ayat demi ayat dan surat demi surat sesuai dengan urutannya dalam mushaf. ${ }^{8}$

Dalam al-Mufassirun Hayatubun wa Manhajatubum, Ali Iyazi mengatakan bahwa tafsir Wahbah ini menggabungkan corak Tafsir bi ar-Ra'yi (berdasar akal) dan Tafsir bi ar-Riwayah (berdasar riwayat), serta menggunakan bahasa kontemporer yang lugas dan mudah dimengerti. Ia menulis tafsir ini sudah merampungkan dua bukunya, Usul al-Figh al-Islami dan al-Fiqh al-Islami wa Adillatubu.

Tafsir ini ditulis berdasar pada keprihatinan Wahbah atas pandangan yang menyudutkan tafsir klasik karena dianggap tidak mampu menawarkan solusi atas problematika kontemporer. Di tempat terpisah, di mata Wahbah, para Mufassir kontemporer banyak melakukan penyimpangan interpretasi terhadap ayat Al-Qur'an dengan dalih pembaruan. Karena itulah, Wahbah berpendapat bahwa tafsir klasik harus dikemas dengan gaya bahasa kontemporer dan metode yang konsisten sesuai dengan ilmu pengetahuan modern tanpa ada penyimpangan interpretasi. Lalu lahirlah al-Tafsir al-Munir yang memadukan orisinalitas tafsir klasik dan keindahan tafsir kontemporer. Dengan begitu apik, Wahbah mengawinkan keduanya.

Dalam pengantar tafsir al-Munir, Wahbah menerangkan bahwa penafsirannya berlandaskan pada ayat Al-Qur'an dan hadis-hadis shahih.

5 Sayyid Muhammad Ali Ayazi, Al-Mufassirun Hayatubum wa Manabijubum, (Teheran: Wizanah al-Tsiqafah wa al-Insyaq al-Islam, th. 1993),h.685

6 M. Izzan, Metodologi Ilmu Tafsir, (Bandung: Tafakkur,2007), h. 104.

7 Wahbah Az-Zuhayli, Tafsîr Al-Munîr Fi Al-'Aqîdah wa Asy-Syarî'ab wa alManhaj, (Dimasyq : Dar al-Fikri, 1998),h. 81-86

8 Nasruddin Baidan, Metode Penafsiran al-Qur'an, (Yogyakarta: Pustaka Pelajar, 2002), 68. 
Ia mengurai asbabun nuzul dan Takbrij al-Hadith, menghindari ceritacerita Isra'iliyyat, riwayat yang lemah, dan polemik yang berlarut-larut. Tafsir ini dipublikasikan oleh penerbit Maktabah al-Babi al-Halabi (Kairo) pada tahun 1957 M. ${ }^{9}$

Dari penjelasan diatas penulis dapat merinci bahwa dalam metode tafsir yang digunakan oleh Wahbah az-Zuhaily dilihat dari berbagai segi,diantaranya adalah:

a. Segi Sumber, yakni penggabungan antara tafsir bi al-Ra'yi, tafsir bi al-Ma'tsur dan bi al-Iqtiron.

b. Segi cara penjelasan, yakni menggunakan Muqorin dan Bayani

c. Segi keluasan penjelasan, yaitu menggunakan metode Ijmali dan alTafsily.

d. Segi sasaran dan tertib ayat, dengan metode tahlili, maudhu'i, dan nuzuli.

\section{Kecenderungan/Alirannya}

Wahbah dibesarkan di kalangan ulama-ulama madhab Hanafi, yang membentuk pemikirannya dalam madhab fiqh, walaupun bermadhab Hanafi, ${ }^{10}$ namun dia tidak fanatik dan menghargai pendapat-pendapat madhab lain, hal ini dapat dilihat dari bentuk penafsirannya ketika mengupas ayat-ayat yang berhubungan dengan Fiqh.

Terlihat dalam membangun argumennya selain menggunakan analisis yang lazim dipakai dalam fiqh juga terkadang menggunakan alasan medis, dan juga dengan memberikan informasi yang seimbang dari masing-masing madhab, kenetralannya juga terlihat dalam penggunaan referensi, seperti mengutip dari Ah\} kam al-Qur'an karya al-Jashshas untuk pendapat madhab Hanafi, dan Ah\} kam al-Qur'an karya al-Qurtubi untuk pendapat madhab Maliki.

Sedangkan dalam masalah teologis, beliau cenderung mengikuti paham ahl al-Sunnah, tetapi tidak terjebak pada sikap fanatis dan menghujat madhab lain. Ini terlihat dalam pembahasannya tentang masalah "Melihat Tuhan" di dunia dan akhirat, yang terdapat pada surat al-An'am ayat $103 .{ }^{11}$

9 Saiful Amin Ghofur,h.174

${ }^{10}$ Sayyid Muhammad 'Ali Ayazi, h.684.

${ }^{11}$ Menurutnya abshar tidak bisa melihat hakekat Allah yang dikaitkan dengan 
Sebelum menafsirkan surat al-Fatihah, Wahbah terlebih dahulu menjelaskan wawasan yang berhubungan dengan ilmu al-Qur'an. Dalam proses penafsiran selanjutnya, ia selalu menguraikan keutamaan dan kandungan surah serta sejumlah tema yang terkait dengan surah tersebut. Tema tersebut lantas diungkap dari tiga aspek.

Pertama, aspek bahasa. Ia mengudar istilah-istilah yang termaktub dalam ayat sembari mengupas segi balaghah dan gramatika bahasanya.

Kedua, aspek tafsir dan bayan. Wahbah memaparkan ayat dengan bahasa yang ringan sehingga diperoleh kejelasan makna. Jika tidak ada permasalahan yag pelik, ia menyingkat pembahasannya. Akan tetapi, jika ayat yang ditafsir memuat permasalahan tertentu, Wahbah menyuguhkan penjelasan yang relative panjang, seperti ketika menafsirkan ayat yang berkaitan dengan problem naskh.

Ketiga, aspek fiqh kehidupan dan hukum (Fiqh al-Hayah wa alAbkam). Dalam aspek ini, Wahbah merinci sejumlah kesimpulan ayat terkait dengan realitas kehidupan manusia.

Dalam tafsir al-Munir karya Wahbah az-Zuhayli ini kecenderungannya terhadap bahasa atau lughah bila dilihat dari penulisannya,sedangkan dalam hukum yang tedapat dalam karyanya lebih cenderung pada paham abl al-Sunnah.

\section{Keistimewaan dan contohnya}

Keistimewaan Tafsir Munir ialah terdapat pada metode pembahasannya yang secara merata, urut dan tuntas mulai dari surah al-Fatihah sampai dengan surah an-Nas, berdasarkan urutan surah dalam al-Mushaf alUsmani. Hal ini sangat mempermudah dalam memahami maksud dan penjelasan setiap surah yang ada didalam tafsir Munir.

Adapun keistimewaan yang utama bahwa tafsir Munir menggunakan metodologi bi al-Ma'tsur dan al-Ra'yi. Bi al-Ma'tsur yakni menafsirkan al-Qur'an dengan ayat al-Qur'an, menafsirkan dengan hadith Nabi, riwayat dari para Sahabat, Tabi' in, dan Tabi'u at-Tabi' in. Metodologi ini adalah metodologi terbaik dalam manafsirkan al-Qur'an sebagaimana

QS. Al-Baqarah 255, dan pendapat Ibnu Abbas bahwa abshar tidak bisa melihatNya di dunia Tetapi orang yang beriman akan melihatNya di Akhirat dikaitkan dengan QS. Al-Qiyamat 22-23 dan hadist shahihain انكم سترون ربكم يوم القيامة كما ترون القمر ليلة البدر , lihat Wahbah az-Zuhayli, Tafsir munir, h.315-316. 
yang diungkapkan oleh Shaikhul Islam Ibnu Taymiyah, Ibnu Kathur, dan Imam al-Zarkashi. ${ }^{12}$ Beliau menyajikan dengan gaya bahasa dan redaksi yang sangat teliti, penafsirannya juga disesuaikan dengan situasi yang berkembang dan dibutuhkan dalam di tengah-tengah masyarakat.

Contoh penafsiran Wahbah az-Zuhaily dalam Ayat Ahkam tentang Ibadah dan Muamalat.

Dalam menafsirkan ayat-ayat Ahkam Wahbah mengambil langkahlangkah, diantaranya:

1. Menentukan Dilalah an-Nash yang terdapat dalam ayat tersebut.

2. Menentukan jenis ayat tersebut, apa Mutashabihat atau Mubkamat.

3. Memperhatikan kaidah-kaidah yang berlaku dalam istinbat $\}$ ayat abkam.

4. Memperhatikan kaidah umum yang berhubungan dengan al-Qur'an. ${ }^{13}$

Ada dua aspek ayat ahkam yang ditafsirkan oleh Wahbah yaitu, yang pertama aspek ibadah, diantara yang dikaji dalam aspek ini adalah permasalahan haid, menghadap kiblat, dan shalat Qashr. Wahbah hanya mengemukakan beberapa pendapat yang berhubungan dengan shalat Qashr, seperti pendapat ulama Hanafi ulama Shafi i mengenai hukum shalat Qashr. Jika kalangan Hanafi berpendapat bahwa shalat Qashr bagi musafir adalah suatu keharusan `azimah berdasarkan hadith Umar, maka kalangan Shafi i menganggapnya rukhsah atau takhyir berdasarkan Hadith 'Aishah, dalam masalah ini Wahbah tidak menentukan pendapat pribadinya dan tidak melakukan tarjih terhadap perbedaan tersebut.

Kedua, aspek muamalat, diantara aspek yang dikaji dalam masalah muamalat adalah kawin lintas agama, adil dalam menetapkan hukum, etika memasuki rumah, dan ayat-ayat tentang gender. ${ }^{14}$

Penulis mengambil contoh penafsiran Wahbah tentang ayat ahkam dengan pertimbangan bahwa beliau adalah seorang fuqaha, adapun contoh yang akan diambil adalah tema "al-Haiz wa Abkamubu" yang terdapat dalam surat al-Baqarah ayat 222-223.

Tafsir Surah Al-Baqarah Ayat 222-223

${ }^{12}$ ht t p://pemudabugis.multiply.com/journal/item/25 $7 /$ T_A_F_S_I_R_M_U_N_I_R/3Feb2009

${ }_{13}$ Wahbah Az-Zuhayli, Tafsîr Al-Munîr Fi Al-'Aqîdah wa Asy-Syarî'ab wa alManbaj. 234

${ }^{14}$ http://referensiagama.blogspot.com/2011/01/sekilas-tentang-tafsir-munir. html 


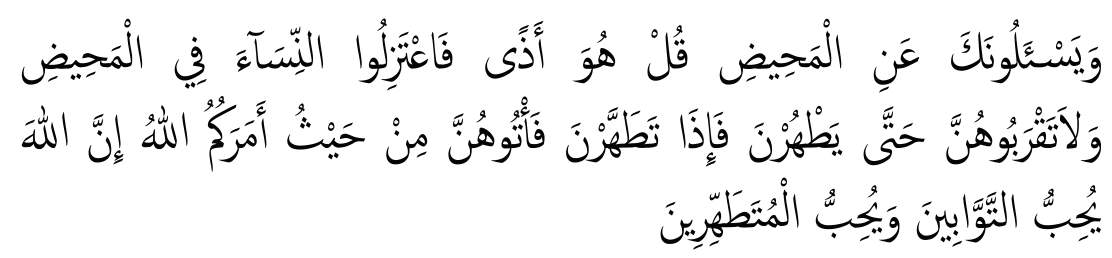

Artinya" Mereka bertanya kepadamu tentang haidh. Katakanlah: "Haid itu adalah suatu kotoran". oleh sebab itu hendaklab kamu menjaubkan diri dari wanita di waktu haidh; dan janganlah kamu mendekati mereka, sebelum mereka suci. apabila mereka Telah suci, Maka campurilab mereka itu di tempat yang diperintabkan Allab kepadamu. Sesunggubnya Allab menyukai orangorang yang bertaubat dan menyukai orang-orang yang mensucikan diri."

Hendaklah menjauhkan diri maksudnya ialah menyetubuhi wanita di waktu haid.

Dan janganlah kamu mendekati mereka, sebelum mereka suci maksudnya ialah sesudah mandi. Adapula yang menafsirkan sesudah berhenti darah keluar.

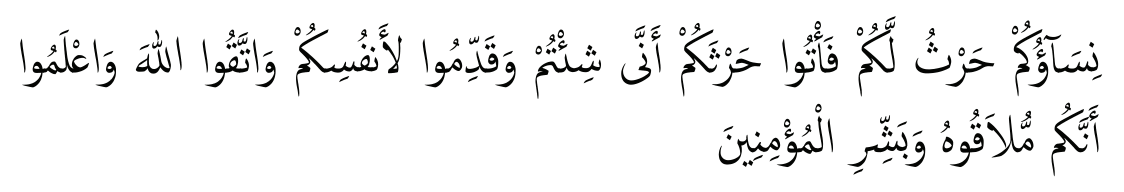

Artinya"Istri-istrimu adalah (seperti) tanah tempat kamu bercocok tanam, Maka datangilab tanah tempat bercocok-tanammu itu bagaimana saja kamu kehendaki. dan kerjakanlab (amal yang baik) untuk dirimu, dan bertakwalah kepada Allah dan Ketahuilah babwa kamu kelak akan menemui-Nya. dan berilab kabar gembira orang-orang yang beriman."

\section{Penutup}

Tafsir al-Munir merupakan tafsir kontemporer, yang disusun oleh ahli fiqh yakni Wahbah az-Zuhaily yang dilahirkan di Shiria, Damaskus. Dalam menafsirkan al-Qur'an dalam tafsir al-Munirnya beliau menggunakan gaya bahasa yang mudah dicerna dan dipahami serta analisis-analisis yang relevan untuk menjawab pertanyaan-pertanyaan yang muncul pada masa sekarang dan menjawab kegelisahan pengarang tentang keadaan jaman di mana kecenderungan pada gaya hidup hedonisme masyarakat, semakin menjauhkannya dari al-Qur'an. 


\section{DAFTAR PUSTAKA}

Ayazi, Sayyid Muhammad Ali. Al-Mufassirun Hayatubum wa Manahijubum. Teheran: Wizanah al-Tsiqafah wa al-Insyaq al-Islam, th. 1993

Baidan, Nasruddin, Metode Penafsiran al-Qur'an, Yogyakarta: Pustaka Pelajar, 2002,

Ghofur, Saiful Amin. Profil Para Mufasir Al-Qur'an. Yogyakarta: Pustaka Insan Madani. 2008.

http://referensiagama.blogspot.com/2011/01/sekilas-tentang-tafsirmunir.html

http://denchiel78.blogspot.com//2010/05/bioigrafi-singkat -wahbahzuhaili.html

http://pemudabugis.multiply.com/journal/item/257/ T_A_F_S_I_R_M_U_N_I_R/3Feb2009

Muhaimin, Kawasan dan Wawasan Studi Islam, Jakarta: Prenada Media, 2005 .

Izzan, M.. Metodologi Ilmu Tafsir. Bandung: Tafakkur. 2007.

Zuhayli (Az), Wahbah. Tafsîr Al-Munîr Fi Al-'Aqîdah wa Asy-Syarî'ab wa al-Manhaj. Dimasyq : Dar al-Fikri. 1998. 